\title{
Getting It Right Isn't Enough: The Appellate Court's Role in Procedural Justice
}

Steve Leben*

\section{INTRODUCTION}

We all know-or surely can sense - that distrust of institutions, including the government, is riding high. While that distrust isn't focused on judges and the legal system, it hasn't excluded them, either. Tribalism is the order of the day; judges are increasingly either on "our" team or "their" team. And respect for "their" team is hard to find.

Yet respect for the legal system is a key to its ability to work. For the most part, we don't send out sheriff's deputies or federal marshals to enforce court orders. We instead rely on voluntary compliance. And voluntary compliance relies on litigants having sufficient respect for the judicial system's legitimacy that they will comply with its orders.

At the trial-court level, as judges handle cases and litigants are often present, decades of social-science research has shown that adherence to procedural-justice principles leads to litigant and public acceptance of the legitimacy of judges and courts. Yet only two articles have focused specifically on ways appellate courts might apply these principles. ${ }^{1}$

This Article explains how and why appellate courts should focus on procedural-justice principles. The "why" is presented in two parts: (1) the public's opinion of courts and judges today, which reflects distrust and a sense of partisanship that undermine court legitimacy; and (2) the application of procedural-justice principles, which has been shown to

\footnotetext{
* Visiting Professor of Law, University of Missouri-Kansas City School of Law; former Judge (20072020), Kansas Court of Appeals. My thanks to Elizabeth Kronk Warner for her very prompt and helpful comments on an early draft; to Kevin Burke, Tom Tyler, and David Rottman for their collaborations on procedural-justice issues for more than a decade; to my faculty colleagues at UMKC Law for their positive response and comments when I presented this material to them; and to the editors of the Kansas Law Review for making the process of getting this into final form an enjoyable and productive editing experience.

1. See Merritt E. McAlister, "Downright Indifference": Examining Unpublished Decisions in the Federal Courts of Appeals, 118 MicH. L. REV. 533 (2020) (examining how unpublished decisions affect the procedural-justice experience of litigants); William C. Vickrey, Douglas G. Denton \& Wallace B. Jefferson, Opinions as the Voice of the Court: How State Supreme Courts Can Communicate Effectively and Promote Procedural Fairness, 48 CT. REV. 74 (2012) (discussing trends in the formation of state supreme court opinions in light of procedural-justice principles).
} 
improve perceptions of legitimacy in the courts. After explaining "why" they should do so, the article shows "how" appellate courts can apply procedural-justice principles throughout the appellate process.

\section{Why We Must Do More: The Public's Sense That the Courts ARE LEGITIMATE IS AT RISK.}

There has been a general loss of confidence in institutions in the United States over the past few decades. Gallup has asked about confidence in seven institutions from 1973 to the present: organized religion, public schools, the Supreme Court, Congress, newspapers, organized labor, and big business. ${ }^{2}$ Respondents rate their confidence as a great deal, quite a lot, some, very little, or none, with Gallup considering "a great deal" and "quite a lot" as expressions of confidence. ${ }^{3}$ The average confidence among those seven institutions ranged from $44 \%$ to $46 \%$ from 1973 to 1976 , fell to $32 \%$ in 1991 before rebounding to $38 \%$ in 2001, and more recently has settled in at about $27 \%$ from 2007 to $2019 .{ }^{4}$ In 2020, during the Covid-19 pandemic, confidence rose sharply for schools (with the percentage having a "great deal" or "quite a lot" of confidence rising from $29 \%$ to $41 \%$ ) but changed little for the other seven institutions polled. ${ }^{5}$

This loss of confidence in institutions is not only well documented by survey-research firms but also recognized by the public. More than threequarters of adults say that compared to 20 years ago Americans are less confident in the federal government. ${ }^{6}$

There's no reason to think that this loss of confidence focuses on courts or judges. In the Gallup survey, confidence in the United States Supreme Court declined only 5 percentage points from 1973 to 2020, while confidence in Congress declined by 29 percentage points and

2. Confidence in Institutions, GALLUP, https://news.gallup.com/poll/1597/confidenceinstitutions.aspx [https://perma.cc/VG3C-6G2Z] (last visited Oct. 11, 2020) (showing annual data through 2020).

3. See id.

4. Lydia Saad, Military, Small Business, Police Still Stir Most Confidence, Gallup (June 28, 2018), https://news.gallup.com/poll/236243/military-small-business-police-stir-confidence.aspx [https://perma.cc/T8D2-SA5C]; Confidence in Institutions, supra note 2.

5. See Megan Brenan, Amid Pandemic, Confidence in Key U.S. Institutions Surges, GalluP (Aug. 12, 2020), https://news.gallup.com/poll/317135/amid-pandemic-confidence-key-institutionssurges.aspx [https://perma.cc/AXK6-8UCL] (noting rise in confidence in public schools and the medical system while confidence in other institutions was largely unchanged).

6. In a Pew Research Center survey taken in November and December 2018, 75\% of respondents said that the level of trust in the federal government had been shrinking. Lee Rainie, Scott Keeter \& Andrew Perrin, Trust and Distrust in America, Pew RsCH. CTR. (July 22, 2019), https://www.people-press.org/2019/07/22/trust-and-distrust-in-america/ [https://perma.cc/7SWM$\mathrm{M} 84 \mathrm{U}]$. 
confidence in organized religion dropped by 23 points. ${ }^{7}$ But confidence in courts, judges, and the criminal-justice system has fallen too. And judges and lawyers need to know about it because it affects the way they should interact with court participants and the public.

Let's start with individual attorneys and judges. Most of them deal with clients, litigants, witnesses, and others one at a time. Perhaps there's a reservoir of trust for lawyers and judges as individuals in these one-onone meetings.

Unfortunately, that's not the case. Gallup has a survey question it regularly asks about various professions: "Please tell me how you would rate the honesty and ethical standards of people in these different fieldsvery high, high, average, low, or very low?" $\quad$ The last time the survey included both judges and lawyers was December $2017 .{ }^{9}$ Only $43 \%$ said judges had high or very high standards for honesty and ethics; the number for lawyers was $18 \%{ }^{10}$ Judges were between day-care providers (46\%) and auto mechanics (32\%); lawyers were only a few points above members of Congress (11\%) and lobbyists (8\%). ${ }^{11}$ Leading the pack were nurses $(82 \%)$, military officers $(71 \%)$, grade-school teachers $(66 \%)$, and medical doctors $(65 \%){ }^{12}$ So it's not impossible to score well on a rating of honesty and ethics. ${ }^{13}$

But when you realize that judges and lawyers have special training in law and ethics - and codes of conduct that govern our behavior - judges and lawyers don't do nearly as well as they would surely hope to do. And views of judges, like trust in institutions, are moving in the wrong direction. The percentage rating judges' honesty and ethics as high or very high dropped from 53\% in 1999 to $43 \%$ in $2017 .{ }^{14}$ For lawyers, the picture has been fairly poor for decades, with those rating honesty and ethics high or very high ranging over the past three decades from a high of $27 \%$ in

7. Confidence in Institutions, supra note 2 (comparing combined percentage of respondents with "a great deal" or "quite a lot" of confidence in the institution).

8. Megan Brenan, Nurses Keep Healthy Lead as Most Honest, Ethical Profession, GaLluP (Dec. 26, 2017), https://news.gallup.com/poll/224639/nurses-keep-healthy-lead-honest-ethicalprofession.aspx [https://perma.cc/7JUX-4VY9]. For historical trends for all the professions Gallup tracks, see Honesty/Ethics in Professions, GALLUP, https://news.gallup.com/poll/1654/honesty-ethicsprofessions.aspx [https://perma.cc/T6Q8-AUZR] (last visited Oct. 11, 2020).

9. See Honesty/Ethics in Professions, supra note 8.

10. Brenan, supra note 8 .

11. Id.

12. Id.

13. Nurses continue to score well (85\% "high" or "very high") while lawyers do not ( $22 \%$ "high" or "very high") in the most recent Gallup survey. See RJ Reinhart, Nurses Continue to Rate Highest in Honesty, Ethics, GaLluP (Jan. 6, 2020), https://news.gallup.com/poll/274673/nursescontinue-rate-highest-honesty-ethics.aspx [https://perma.cc/B9P3-SQLM].

14. Honesty/Ethics in Professions, supra note 8. 
1985 to a low of $13 \%$ in 1999 and 2009 to $22 \%$ in $2019 .{ }^{15}$

When we broaden our view to the institutional level, the United States Supreme Court is often considered the bellwether for the court system. But approval ratings for the Supreme Court have changed dramatically since its 2000 decision in Bush v. Gore ${ }^{16}$ the five-to-four ruling that decided the 2000 presidential election.

Gallup regularly asks respondents whether they "approve or disapprove of the way the Supreme Court is handling its job." ${ }^{\prime 7}$ The overall numbers show a decline in approval and an increase in disapproval. ${ }^{18}$ In fall 2000, shortly before Bush v. Gore, $62 \%$ approved and 29\% disapproved; in fall 2019, $54 \%$ approved and $42 \%$ disapproved. ${ }^{19}$ But twice during that time period approval dipped to $42 \% .{ }^{20}$ Even so, in 2019 and 2020, the Court had a net-positive approval number. ${ }^{21}$

But behind the overall numbers are several divides. First, there's a racial divide. Gallup reports separate figures for whites and non-whites, with 2020 approval at $61 \%$ for whites and 52\% for non-whites. ${ }^{22}$ A 2019 Pew survey showed Blacks and Hispanics generally had lower general trust levels in other people, which correlated with lower trust in institutions. $^{23}$ There's also a persistent divide by race in views of the criminal-justice system, with Blacks more than twice as likely as whites to attribute higher incarceration rates for Black men to discrimination. ${ }^{24}$

Second, a gender divide emerged in Gallup's September 2018

\footnotetext{
15. $I d$.

16. 531 U.S. 98 (2000).

17. Supreme Court, GALLuP, https://news.gallup.com/poll/4732/supreme-court.aspx [https://perma.cc/CAQ9-3YZM] (last visited Oct. 11, 2020).

18. Id.

19. Id.

20. Id. In July 2016, disapproval led approval $52 \%$ to $42 \%$. And in June 2005, disapproval led approval $48 \%$ to $42 \%$. Id.

21. Id. See also Justin McCarthy, Approval of the Supreme Court Is Highest Since 2009, Gallup (Aug. 5, 2020) [hereinafter McCarthy, Approval of the Supreme Court Is Highest Since 2009], https://news.gallup.com/poll/316817/approval-supreme-court-highest-2009.aspx [https://perma.cc/QB5X-UBWE].

22. Jeff Jones \& Lydia Saad, July Wave 1, GAlluP 3 (July 1-23, 2020), https://news.gallup.com/poll/316844/americans-views-supreme-court.aspx [https://perma.cc/AM7VD54J] (last visited Oct. 11, 2020) (data available through link to "Download File 200806SupremeCourt.pdf").

23. See Rainie et al., supra note 6.

24. Frank Newport, Gallup Review: Black and White Attitudes Toward Police, Gallup (Aug. 20 , 2014), https://news.gallup.com/poll/175088/gallup-review-black-white-attitudes-towardpolice.aspx [https://perma.cc/E6PZ-4MQU]. In the 2013 survey, only 19\% of whites attributed the greater incidence of Black males going to prison compared to whites as "mostly due to discrimination," while $50 \%$ of Blacks said it was. Id. Newport reported that Gallup surveys had shown a "racial gap in confidence in police ... throughout the past decade and a half that Gallup has been measuring these trends on an annual basis." Id.
} 
Supreme Court approval survey, taken after the confirmation of Justice Brett Kavanaugh. From 2000 through 2017, approval rates by men and women were quite similar. In 2000, approval by men was $59 \%$ and approval by women $60 \%$; in 2017 , approval by men was $50 \%$ and approval by women $49 \% .^{25}$ But in 2018 , approval by men had risen to $60 \%$ and approval by women had fallen to $43 \% .{ }^{26}$ It's not fair, though, to attribute the gap only to Kavanaugh's nomination. Gallup had done an additional 2018 survey in July, and a 9-point gap was already in place mostly before Kavanaugh was nominated. ${ }^{27}$ And the September data came before sexual-assault allegations against Kavanaugh became public. ${ }^{28}$ As of Gallup's September 2019 survey, a 12-point gender gap remained in place. ${ }^{29}$

Third, a partisan divide emerged after Bush v. Gore. Overall approval of the Court was at $62 \%$ in September $2000,{ }^{30}$ and the approval rate of Democrats was only slightly higher than that of Republicans as the eightyear Clinton presidency ended. ${ }^{31}$ But after Bush v. Gore, Republican approval shot up to $80 \%$ and Democratic approval fell to $42 \%$. $^{32}$ Since then, the views of partisans on both sides have swung dramatically as the White House changed hands (changing public perception of where the Court might head) or major decisions were announced in cases involving the Affordable Care Act or LGBTQ+ rights. ${ }^{33}$ Republican approval fell to a low of 18\% in 2015 after the Court had upheld same-sex marriage rights and the Affordable Care Act. ${ }^{34}$ Democratic approval in 2015 rose to $76 \% .{ }^{35}$ But with the confirmation of two appointees of President Trump, Republican approval had rebounded by 2019 to $73 \%$ while Democratic

\footnotetext{
25. Justin McCarthy, Women's Approval of SCOTUS Matches 13-Year Low Point, GALLUP (Sept. 28, 2018) [hereinafter McCarthy, Women's Approval of SCOTUS], https://news.gallup.com/poll/243266/women-approval-scotus-matches-year-lowpoint.aspx [https://perma.cc/9VM2-6XAH].

26. $I d$.

27. See id.

28. Id.

29. See Jeff Jones \& Lydia Saad, Gallup Poll Social Series: Governance, GaLluP 4 (Sept. $3-$ 15, 2019), https://news.gallup.com/poll/267158/supreme-court-enjoys-majority-approval-start-newterm.aspx [https://perma.cc/NZ5Q-NKEX] (data available at end of article through "View complete question responses and trends" link).

30. Supreme Court, supra note 17.

31. Justin McCarthy, GOP Approval of Supreme Court Surges, Democrats' Slides, GalluP (Sept. 28, 2017) [hereinafter McCarthy, GOP Approval of Supreme Court Surges], https://news.gallup.com/poll/219974/gop-approval-supreme-court-surges-democrats-slides.aspx [https://perma.cc/TTB3-6E8Y].

32. Id.

33. See id.

34. Id.

35. Id.
} 
approval had fallen to $38 \% .^{36}$

If it's true that the judiciary - the least dangerous branch - must rely in some measure on public support, these numbers are troubling. Two writers at FiveThirtyEight.com, a website that tracks public opinion, argued in 2018 that the Supreme Court was "in a weaker position now than at nearly any point in modern history." ${ }^{37}$ Large swaths of the public have significant doubts about our nation's highest court. ${ }^{38}$ And at this point, it's hard to see how that might change or when significant change could occur. Racial and ethnic divisions-and inequality-have been present throughout our history, of course. Gender equity has had its own historic journey, one that has not yet reached fruition. But the partisan divide that now pervades public discourse is its own threat to court legitimacy.

There's a caveat about these reports of division - some of them went away, at least temporarily, in Gallup's 2020 survey, which was taken shortly after the Court's October 2019 Term ended this July, during the Covid-19 pandemic but before Justice Ruth Bader Ginsburg's September 18,2020 death. $^{39}$

This year's survey didn't show either a partisan divide or one based on gender. Approval was roughly the same for Republicans (60\%), Democrats (56\%), and Independents (57\%), just as it was for men $(55 \%)$ and women $(60 \%){ }^{40}$ Because these results differed from past surveysespecially the partisan divide that had persisted since 2000 - one would presume the shift reflects decisions made by the Court this Term. There were high-profile decisions that may have led to similar approval scores by people on each side of these divides. Decisions late in the Term included protecting LGBT workers from employment discrimination ${ }^{41}$ and rejecting President Donald Trump's attempt to end the Deferred Action for Childhood Arrivals (DACA) program. ${ }^{42}$ On abortion, the Court upheld

36. Lydia Saad, Supreme Court Enjoys Majority Approval at Start of New Term, GALLUP (Oct. 2, 2019), https://news.gallup.com/poll/267158/supreme-court-enjoys-majority-approval-start-newterm.aspx [https://perma.cc/3CUE-H8NX]. For Pew Center data on the partisan divide, see Claire Brockway \& Bradley Jones, Partisan Gap Widens in Views of the Supreme Court, Pew RsCH. CTR. (Aug. 7, 2019), https://www.pewresearch.org/fact-tank/2019/08/07/partisan-gap-widens-in-views-ofthe-supreme-court/ [https://perma.cc/K2RG-SS82]. In the Pew data, $81 \%$ of Democrats and $76 \%$ of Republicans had a favorable view of the Supreme Court in 1997. Id. In 2019, 75\% of Republicans had a favorable view but only $49 \%$ of Democrats did. Id.

37. Amelia Thomson-DeVeaux \& Oliver Roeder, Is the Supreme Court Facing a Legitimacy Crisis?, FiveThiRTYEight (Oct. 1, 2018, 6:00 AM), https://fivethirtyeight.com/features/is-thesupreme-court-facing-a-legitimacy-crisis/ [https://perma.cc/JL8L-Z6KE].

38. See id.

39. McCarthy, Approval of the Supreme Court is Highest Since 2009, supra note 21.

40. Id.; Jones \& Saad, July Wave 1, supra note 22, at 3.

41. Bostock v. Clayton Cnty., 140 S. Ct. 1731, 1737 (2020).

42. DHS v. Regents of the Univ. of Cal., 140 S. Ct. 1891, 1901 (2020). 
abortion rights but did so in a case in which Chief Justice Roberts, whose vote was pivotal to the five-member majority, announced in a concurring opinion a test that some thought would allow greater abortion restrictions going forward. ${ }^{43}$ The net result of the Term's opinions left approval by Republicans and men stable while lifting the approval level by women, Democrats, and Independents. ${ }^{44}$

At least for the partisan divide, which had been in place since 2000, it's hard to see how and why that partisan divide would dissipate on any permanent basis. A 2019 Pew report found the partisan divide an increasingly personal one, with increasing percentages on each side finding members of the opposing party closed-minded or immoral. ${ }^{45}$ In the Pew survey, a majority of both Republicans and Democrats said that even on nonpolitical matters, members of the other party probably don't share many of their other values and goals. ${ }^{46}$ While the high-profile rulings near the end of the October 2019 Term may have resonated, though for different reasons, with both Republicans and Democrats, that may not play out the same way again.

When we move our focus away from any single survey and return to look at the bigger picture, we still find diminished trust in institutions generally. We have large segments of the public with serious doubts about the nation's highest court. ${ }^{47}$ And, for the most part, we have a partisan divide that in most recent years leads one side or the other to have a stronger disapproval of the Court than had been the case before Bush v. Gore and our recent hyper-partisanship. ${ }^{48}$ As this Article was being edited, intense partisan warfare had taken place over the replacement of the Justice Ginsburg, and Justice Amy Coney Barrett had just been confirmed. ${ }^{49}$ It seems unlikely that the partisan divide in Court approval

43. June Med. Servs. L.L.C. v. Russo, 140 S. Ct. 2103, 2139 (2020). See also Melissa Murray, The Supreme Court's Abortion Decision Seems Pulled from the 'Casey' Playbook, WASH. Post (June 29, 2020, 7:51 PM), https://www.washingtonpost.com/opinions/2020/06/29/problem-with-relyingprecedent-protect-abortion-rights/ [https://perma.cc/38TH-ATVX].

44. See McCarthy, Approval of the Supreme Court Is Highest Since 2009, supra note 21; Jones \& Saad, July Wave 1, supra note 22, at 3.

45. Partisan Antipathy: More Intense, More Personal, PEW RsCH. CTR. (Oct. 10, 2019), https://www.people-press.org/2019/10/10/partisan-antipathy-more-intense-morepersonal/ [https://perma.cc/E9KW-Z6DE].

46. Id.

47. See Supreme Court, supra note 17.

48. See, e.g., McCarthy, GOP Approval of Supreme Court Surges, supra note 31.

49. See, e.g., Ron Elving, Partisan Reaction to Loss of Ginsburg Shows How Much Else Has Been Lost, NPR (Sept. 22, 2020, 10:35 PM), https://www.npr.org/2020/09/22/915152430/partisanreaction-to-loss-of-ginsburg-shows-how-much-else-has-been-lost [https://perma.cc/PY2S-V3X9]; Barbara Sprunt, Amy Coney Barrett Confirmed to Supreme Court, Takes Constitutional Oath, NPR (Oct. 26, 2020, 8:07 PM), https://www.npr.org/2020/10/26/927640619/senate-confirms-amy-coney- 
ratings will not return in 2021.

For individual judges, two surveys from the Annenberg Public Policy Center tell us something useful too. In surveys about courts and judges, they asked questions about whether certain things influenced a state judge's rulings. ${ }^{50}$ When asked whether a judge's ruling "is influenced by his or her personal political views," $75 \%$ said that either to a "Great extent" or a "Moderate extent" they were. ${ }^{51}$ When asked whether a judge's ruling would be affected by a "desire to be promoted to a higher court," $75 \%$ said it would be. ${ }^{52}$

Of course, not every judge is even interested in being promoted to a higher court. And political views wouldn't be of much importance in deciding whether a driver had been speeding or had run through a stop sign. But these questions, like a push poll, ${ }^{53}$ suggest something to the respondent. With judges, these responses suggest that the public has little enough contact with judges that respondents are willing to believe just about anything that might be said about the judge. That could easily be a problem if, for example, the attorney who lost a case suggested to their client that the judge had a bias or was known for a lack of knowledge about the law or made some other claim that would undermine court legitimacy. Or if a judge's own comment suggested a bias. Such things could be true in some cases, but these surveys suggest that people are open to suggestions of possible judicial bias. Judges don't enter the courtroom with a strong reservoir of trust and legitimacy that can be drawn upon. For those who judge the judges - litigants, attorneys, and the general publictrust must be earned in each encounter.

\footnotetext{
barrett-to-the-supreme-court [https://perma.cc/X466-7R3E]; Opinion, The Republican Party's Supreme Court, N.Y. TiMES (Oct. 26, 2020), https://www.nytimes.com/2020/10/26/opinion/amyconey-barrett-supreme-court.html [https://perma.cc/8BTC-HTKM].

50. 2007 Annenberg Public Policy Center Judicial Survey: Exact Question Wording, By Category, ANNENBERG PUB. POL'Y CTR. https://cdn.annenbergpublicpolicycenter.org/Downloads/20071017_JudicialSurvey/Survey_Question s_10-17-2007.pdf [https://perma.cc/3GCD-9Z4C] (last visited Oct. 12, 2020); Kathleen Hall Jamieson \& Michael Hennessy, Public Understanding of and Support for the Courts: Survey Results, 95 GeO. L.J. 899, 899, 901 (2007).

51. See 2007 Annenberg Survey, supra note 50, at 5.

52. Jamieson \& Hennessy, supra note 50, at 901.

53. Push polls, often encountered during political campaigns, are "a form of negative campaigning that is disguised as a political poll." What Is a "Push" Poll?, AM. ASS'N FOR PUB. OPINION RSCH., https://www.aapor.org/ Education-Resources/Resources/What-is-a-Push-Poll.aspx [https://perma.cc/5GW6-VF3X] (last visited Oct. 11, 2020). For example, a telemarketing firm tells the respondent they are participating in survey research but presents information designed to "push" the respondent to a particular side.
} 


\section{The APPlication of Procedural-Justice PrinciPles LEADS to A GREATER SENSE OF COURT LEGITIMACY BY LiTIGANTS AND THE PUBLIC.}

If the bad news is that an overall lack of trust includes courts and judges, the good news is that there is a proven way to improve trust within the court system. And that way is adherence to procedural-justice principles. The research into its effectiveness is so persuasive that researcher David Rottman of the National Center for State Courts called procedural justice "the organizing theory for which 21 st-century court reform has been waiting." 54

Because the term "procedural justice" can have different meanings in different contexts and in different academic fields, we should first define the term as it is being used here. Procedural justice is sometimes used to refer to procedural due process, a legal concept all lawyers know about. But what's discussed here comes mainly out of the work of social psychologists who have looked to see what procedures lead a person to think an authority figure has dealt with them fairly and how being dealt with fairly changes a person's views about the authority figure. ${ }^{55}$ One commentator has defined procedural justice as the proposition that "providing fair and transparent court procedures would result in greater satisfaction and compliance regardless of the substantive outcome of their case." $" 56$

Within that context, let's review the basic principles of procedural justice. They come from research about how court procedures and actors shape the judgments people make about the courts. Researchers vary in the way they label the key factors. ${ }^{57}$ But social psychologist Tom Tyler, the most-cited scholar in this area, has settled on four key things that lead to greater perceptions of fairness in court proceedings:

1. Voice: litigants' ability to participate in the case by expressing their viewpoint before decisions about them are made;

54. David B. Rottman, Procedural Fairness as a Court Reform Agenda, 44 Ct. Rev. 32, 32 (2007-2008).

55. For a discussion of the differences between procedural justice in the legal and psychological literature, see Rebecca Hollander-Blumoff, The Psychology of Procedural Justice in the Federal Courts, 63 Hastings L.J. 127, 132-42 (2011).

56. Lynn Mather, Law and Society, in THE OXFord HANDBOoK OF LAW AND Politics 681, 691-92 (Keith E. Whittington, R. Daniel Kelemen \& Gregory A. Caldeira eds., 2008). Mather notes that Tom Tyler's work has "generated a large body of research testing this idea, and finding considerable support." Id. at 692.

57. See Tom R. Tyler, Robert J. Boeckmann, Heather J. Smith \& Yuen J. Huo, Social JUSTICE IN A DIVERSE SOCIETY 87-94 (1997) (comparing procedural-justice criteria used by leading researchers). 
2. Neutrality: consistently applied legal principles, unbiased decision makers, and a transparency about how decisions are made;

3. Respect: treating individuals with dignity and explicitly protecting their rights; and

4. Trust: authorities are benevolent, caring, and sincerely trying to help the litigants - a trust garnered by listening to individuals and by explaining or justifying decisions that address the litigants' needs. ${ }^{58}$

At least in the state-court system, a consensus has emerged that courts should work to meet these procedural-justice objectives. The American Judges Association, a group made up mainly of state-court judges, approved a white paper urging greater attention to procedural justice in 2007. ${ }^{59}$ The Conference of State Court Administrators (COSCA) (representing the administrative leaders of the state courts) endorsed the paper in $2008,{ }^{60}$ and the Conference of Chief Justices (CCJ) (representing all state chief justices in the United States) joined in 2013. ${ }^{61}$ A joint CCJCOSCA resolution in 2013 urged that state courts integrate procedural justice into judicial-education programs, practice procedural-justice principles in the treatment of court personnel, and measure litigant satisfaction in part based on procedural-justice principles. ${ }^{62}$

The basis for this wide acceptance is an extensive literature demonstrating the importance of procedural justice (also known in this context as procedural fairness). Researchers have convincingly shown that the public's view of the justice system is driven more by how they are treated by the courts than whether they win or lose their particular case. ${ }^{63}$

58. Tom R. Tyler, Procedural Justice and the Courts, 44 CT. REv. 26, 30-31 (2007-2008) [hereinafter Tyler, Procedural Justice]; Tom R. Tyler \& Justin Sevier, How Do the Courts Create Popular Legitimacy?: The Role of Establishing the Truth, Punishing Justly, and/or Acting Through Just Procedures, 77 ALB. L. Rev. 1095, 1105-07 (2014).

59. The American Judges Association's white paper was published in 2007 as Kevin Burke \& Steve Leben, Procedural Fairness: A Key Ingredient in Public Satisfaction, 44 CT. REV. 4 (20072008).

60. Conf. of State Ct. Admins., Resolution 6: In Support of AJA White Paper on Procedural Justice (July 30, 2008), reprinted in 44 CT. REV. 47, 47 (2007-2008).

61. Conf. of Chief Justices \& Conf. of State Ct. Admins., Resolution 12: In Support of State Supreme Court Leadership to Promote Procedural Fairness, at 2 (July 31, 2013), https://cosca.ncsc.org/_data/assets/pdf_file/0024/23694/07312013-support-statesupreme-court-leadership-promote-procedural-fairness-ccj-cosca.pdf [https://perma.cc/9CSC-59RS].

62. Id. The resolution noted that several state courts had begun having judicial-education programs on procedural justice. $I d$. at 1 .

63. See, e.g., David B. Rottman, Adhere to Procedural Fairness in the Justice System, 6 CRIMINOLOGY \& PUB. POL'Y 835, 838 (2007); TYLER ET AL., supra note 57, at 75-76; Jonathan D. Casper, Tom Tyler \& Bonnie Fisher, Procedural Justice in Felony Cases, 22 LAW \& Soc'Y REv. 483, 483, 486-87, 504 (1988); Jason Sunshine \& Tom R. Tyler, The Role of Procedural Justice and Legitimacy in Shaping Public Support for Policing, 37 LAW \& SOC'Y REv. 513, 514-15 (2003) (testing the argument for police legitimacy); JoHN THIBAUT \& LAURENS WALKER, PROCEDURAL JUSTICE: A PSYCHOLOGICAL ANALYSIS 67-96 (1975). 
For example, an extensive study found that perceptions of procedural justice were "the strongest predictor by far" of public confidence in the California state-court system-if litigants or members of the public perceived that the court provided fair treatment in the aspects Tyler identified, their overall opinion of the court system was much more positive. ${ }^{64}$

On top of this effect of improving overall satisfaction with the courts, adherence to procedural-justice principles has also been shown to lead to greater compliance with court orders. ${ }^{65}$ More broadly, studies link people's judgments about the procedural fairness of proceedings to "decision adherence over time; rule-breaking behavior; well-being and recovery; and cooperation" with courts and police. ${ }^{66}$ Tyler's studies trace these results back to the greater sense of legitimacy that an authority figure or institution gains through the use of procedural-justice principles. ${ }^{67}$

These results are found even in some of the most difficult of legal proceedings, like domestic-violence cases. ${ }^{68}$ And while some demographic groups have less trust in institutions-including the judiciary - than others, the elements of procedural justice dominate people's reactions to the legal system across ethnic groups, across gender, and across income and educational levels. ${ }^{69}$

64. David B. Rottman, Trust and Confidence in the California Courts: A Survey of the Public and Attorneys, NAT'L CTR. FOR STATE CTS. 24-26 (2005) [hereinafter Rottman, Trust and Confidence in the California Courts], https://www.courts.ca.gov/documents/PTC_phase_I_web.pdf [https://perma.cc/WRC7-B2AQ].

65. See, e.g., Tom R. TYler, Why People Obey the LaW 172 (1990); Tom R. Tyler, Psychological Perspectives on Legitimacy and Legitimation, 57 ANN. REV. PSYCH. 375, 393 (2006); Tom R. Tyler, Procedural Justice, Legitimacy, and the Effective Rule of Law, 30 CRIME \& JUST. 283, 286 (2003); Burke \& Leben, supra note 59, at 7; Tyler, Procedural Justice, supra note 58, at 28; Tom R. Tyler, Lawrence Sherman, Heather Strang, Geoffrey C. Barnes \& Daniel Woods, Reintegrative Shaming, Procedural Justice, and Recidivism: The Engagement of Offenders' Psychological Mechanisms in the Canberra RISE Drinking-and-Driving Experiment, 41 LAW \& SOC'Y REV. 553, 575-78 (2007); David B. Rottman \& Tom R. Tyler, Thinking About Judges and Judicial Performance: Perspective of the Public and Court Users, 4 OÑATI Socio-Legal SERIES 1046, 1049-50 (2014); Kevin S. Burke, Just What Made Drug Courts Successful?, 36 New ENG. J. ON CRIM. \& CIV. CONFINEMENT 39, 56-58 (2010); Allison D. Redlich, Voluntary, But Knowing and Intelligent?, 11 PSYCH. PUB. POL'Y \& L. 605, 610 (2005); Deborah A. Eckberg \& Marcy R. Podkopacz, Family Court Fairness Study, Fourth Jud. Dist. OF MinN. Rsch. Div. 29, 32-33, 34-35, 38 (May 2004), http://www.mncourts.gov/Documents/4/Public/Research/Family_Court_Fairness_Report_Final_(200 4).pdf [https://perma.cc/E2CG-HGZM] (last visited Oct. 12, 2020); Katherine M. Kitzmann \& Robert E. Emery, Procedural Justice and Parents' Satisfaction in a Field Study of Child Custody Dispute Resolution, 17 LAW \& Hum. BeHAV. 553, 554-55 (1993); Tyler \& Sevier, supra note 58, at 1101-02, 1104-05.

66. Tyler \& Sevier, supra note 58, at 1101-02 (footnotes omitted).

67. See id. at 1102-05.

68. See Eckberg \& Podkopacz, supra note 65, at 34-35. See also Raymond Paternoster, Robert Brame, Ronet Bachman \& Lawrence W. Sherman, Do Fair Procedures Matter? The Effect of Procedural Justice on Spouse Assault, 31 LAW \& Soc'Y REV. 163, 192-95 (1997).

69. Burke \& Leben, supra note 59, at 17; Tyler, Procedural Justice, supra note 58, at 27-28. 
Since the readers of this Article are most likely lawyers and judges, a final point should be made about how the views of lawyers and judges differs from that of the general public. In a California study that included both lawyers and the public (both with and without recent court experiences), researchers looked at the relationship between overall court approval and the respondents' views about procedural justice. ${ }^{70}$ For the public, views about procedural justice (i.e., whether the courts handled cases through fair procedures) were more closely tied to overall approval of the California courts than whether the public thought the courts got the outcomes right. ${ }^{71}$ But for lawyers, the result was the opposite: lawyers' overall approval of the courts was more closely tied to whether the lawyers thought courts got the outcomes right than whether cases were handled through fair procedures. ${ }^{72}$

Why might that be? Traditional law-school education focuses on outcomes; first-year students learn the holding of each case and work them into an outline of substantive legal rules. In addition, of course, attorneys are more familiar with a court's typical procedures and thus are less likely to feel lost during the process as the public may be. But whatever the cause may be, attorneys may not be as attuned as the public is to how important procedural justice can be.

A similar result showed up in a study of judges. ${ }^{73}$ A researcher had some federal appellate judges review police-citizen encounters raising Fourth Amendment issues. ${ }^{74}$ Half of the panel read about a search that had been done fairly, with polite police who had identified themselves and who had listened to the citizen's side of the story. ${ }^{75}$ The other half read about a search conducted without much procedural justice: the officers had been rude, hadn't initially identified themselves, and didn't let the citizens explain their side. ${ }^{76}$ The judges recognized the differences in the scenarios, but that didn't affect the way they decided the cases. ${ }^{77}$ Psychologist Larry Heuer concluded that "the meaning of fairness among judges is considerably different .... [and] outcome concerns had a greater influence among judges than the procedural criteria of trust, neutrality, and

\footnotetext{
70. Rottman, Trust and Confidence in the California Courts, supra note 64, at 24-30.

71. Id. at 25 .

72. Id.

73. See Larry Heuer, What's Just About the Criminal Justice System? A Psychological Perspective, 13 J.L. \& POL'Y 209, 214-18 (2005).

74. Id. at $215-16$.

75. Id. at 216

76. $I d$.

77. Id. at $216-17$.
} 
standing" that constitute the public's understanding of procedural justice. ${ }^{78}$ That may be a good thing with regard to judges getting the right legal ruling, but there's room for considerable tension between the way lawyers and judges look at things (focused on rules and cold reality) and the way others do (focused on procedural fairness).

Broadly, then, there's extensive evidence that procedural justice leads to a greater sense of public legitimacy for judges and the courts, better acceptance of judicial decisions, and better compliance with court orders. There's also a tendency among lawyers and judges to undervalue this impact.

That tendency applies at the appellate level too. The next section of this Article looks at how procedural justice is undervalued there, along with steps that could be taken to improve public perceptions of appellate courts.

\section{STEPS APPELlate COURTS CAN TAKE TO IMPROVE PROCEDURAL JUSTICE.}

Although we know that adhering to procedural-justice principles in general leads to improved legitimacy for the courts, the studies looking at this have been done either at the trial-court level or have looked mainly at overall satisfaction with a court system. Other than public-opinion surveys about the United States Supreme Court, no published studies have tried to evaluate procedural justice in the appellate courts with data from appellate-court users.

There's reason to think that what appellate courts do would affect overall satisfaction with the court system. If nothing else, appellate courts - especially state supreme courts and the United States Supreme Court-have much higher visibility than trial courts. When a state supreme court rules that its state's school-finance system is unconstitutional, that gets noticed. And when the United States Supreme Court decides issues about abortion rights or marriage equality, that's on every newscast.

Despite this, only two prior articles appear to have focused on the application of procedural-justice principles to appellate courts. In one, a former state chief justice and two court administrators applied proceduraljustice principles to suggest ways that state supreme courts might communicate more effectively with the public, both in their opinions and the way courts communicate with the public when their opinions are

78. Id. at 217. 
issued. ${ }^{79}$ Their suggestions include that courts write shorter opinions, make sure that a good summary is provided to the media (both in the opinion and separately), and explain the court's role. ${ }^{80}$ In the other, a law professor found that a large percentage of the decisions of federal intermediate appellate courts consisted of very short opinions that were devoid of any reasoned explanation of the decision. ${ }^{81}$ Based on procedural-justice principles, she recommends that all opinions contain at least a summary of the key issues and relevant law, along with some application of that law to the facts. ${ }^{82}$

There has also been some research in the related field of therapeutic jurisprudence. That field was created through the work of law professors David Wexler and Bruce Winick. ${ }^{83}$ The essence of therapeutic jurisprudence is that encounters with the legal system "can produce therapeutic or antitherapeutic consequences" on those having the encounters. ${ }^{84}$ Wexler and Winick urge using behavioral-science insights to help the legal system produce the most therapeutic consequences possible. ${ }^{85}$ Because those who write about therapeutic jurisprudence seek insights from behavioral sciences, some of them have relied in part on the insights of social psychologists about procedural justice. ${ }^{86}$ Five articles have suggested changed appellate-court approaches based on insights from therapeutic jurisprudence ${ }^{87}$ this Article discusses those ideas as they fit into the discussion here.

Even though study of this area is limited, litigants, attorneys, and even the general public will form procedural-justice perceptions about appellate courts. In some situations discussed here, those perceptions would not be

\footnotetext{
79. See Vickrey et al., supra note 1 , at 74 .

80. Id. at 79-81.

81. McAlister, supra note 1 , at $567-82$.

82. Id. at 591-94.

83. See generally DAVID B. WeXler \& BRUCE J. Winick, LAW IN A THERAPEUtic Key: DEVElopMENTS IN THERAPEUTIC JURISPRUDENCE (1996); DAVID B. WEXLER \& BRUCE J. WiNICK, ESSAYS IN THERAPEUTIC JURISPRUDENCE (1991); JUdGING IN A THERAPEUTIC KEY: THERAPEUTIC JURISPRUDENCE AND THE COURTS (Bruce J. Winick \& David B. Wexler eds., 2003).

84. JUDGING IN A THERAPEUTIC KEY, supra note 83, at 7.

85. See Steve Leben, Book Review, 26 JuST. SYS. J. 109, 109-10 (2005) (reviewing JUDGING IN A THERAPEUTIC KEY, supra note 83).

86. See, e.g., JUdGING IN A Therapeutic Key, supra note 83, at 7-8.

87. See David B. Wexler, Elevating Therapeutic Jurisprudence: Structural Suggestions for Promoting a Therapeutic Jurisprudence Perspective in the Appellate Courts, 5 PHX. L. REV. 777, 786-88 (2012); Amy D. Ronner, Therapeutic Jurisprudence on Appeal, 37 CT. REV. 64, 65-66 (2000); Amy D. Ronner \& Bruce J. Winick, Silencing the Appellant's Voice: The Antitherapeutic Per Curiam Affirmance, 24 Seattle U. L. ReV. 499, 505-07 (2000); Nathalie Des Rosiers, From Telling to Listening: A Therapeutic Analysis of the Role of Courts in Minority-Majority Conflicts, 37 CT. REV. 54, 57-58 (2000); Steve Leben, Thoughts on Some Potential Appellate and Trial Court Applications of Therapeutic Jurisprudence, 24 SEATTLE U. L. REV. 467, 472-75 (2000).
} 
good ones. But changes, some quite modest, would be likely to improve those perceptions.

\section{A. Motion Practice}

Appellate courts get lots of motions. The Kansas Court of Appeals gets about 10,000 each year. ${ }^{88}$ But no court is so well staffed that it could issue detailed written orders that show careful consideration of each of 10,000 motions and still keep up with the rest of the work. After all, an appellate court's main task is deciding the cases based on briefing and argument, not figuring out all those motions.

But I suspect that sometimes lawyers and litigants rightly wonder whether appellate judges are paying any attention at all to the substance of the motions they've filed. In the Kansas Court of Appeals, rulings were traditionally handled by a single judge, who would write something like, "Accepted," or "Denied," or "Denied on present showing," on the first page of the motion. And that was all of the order. If an attorney or litigant received such an order, how confident could they be that the court understood what had been requested, had respected the party's right to ask, cared about the party's substantive rights, and applied neutral principles in its decision? To any who asked or thought about those questions, the answers wouldn't be good ones.

Even so, doesn't the court have a ready excuse - that there are too many motions to provide detailed orders? Maybe not. When you look behind the 10,000-motion number on my former court, you would find that replies were filed in only about five percent of those motions. ${ }^{89}$ Thus, even if we assume that all motions with replies are opposed (while in fact some replies simply say that the other party has no objection), that means that only 5 percent of the court's motions were contested. Now you're down to only about 40 motions per month that might need something more detailed.

My guess is that only a few of the 40 or fewer contested motions per month need to have something more than the traditionally terse handwritten order. In recent years, though, the judges who handle the court's motions have been preparing explanatory written orders fairly often as they've deemed it appropriate. Whether explicitly focused on procedural justice or not, the increased use of written orders has

88. See Kansas Court of Appeals, Caseload Activity Summary, Fiscal Year 2019, at 3, https://www.kscourts.org/KSCourts/media/KsCourts/Case\%20Statistics/Annual\%20Reports/2019/20 19-Appellate-Court.pdf [https://perma.cc/T26Z-WZWD] (last visited Oct. 12, 2020).

89. See id. 
undoubtedly helped in public perceptions of procedural justice in the court's handling of motions. But to the extent appellate judges throughout the country are not yet doing so, they should start thinking more carefully about perceptions of procedural justice when ruling on motions. What $d o$ lay people think when their attorney tells them that their motion has been "denied on present showing?"

In some cases, a matter being decided by motion is significant—like a party's motion for a stay pending appeal or a party's motion to dismiss for lack of jurisdiction. If the parties are represented by counsel, they may pay substantial attorney fees to present the issue to the court on that motion. And if they get back a terse order- "The motion for a stay pending appeal is denied."-what are they to think? Perhaps the party seeking the stay will conclude that their attorneys didn't know what they were doing. ("How could my attorneys charge me that much money when the court says the matter is such a simple one it could be denied in less than ten words?") Perhaps the court misapplied the legal standard for a stay; if so, the losing party wouldn't know it and thus couldn't know to move for reconsideration.

In other cases, the motion itself may not be all that significant, but a party still may need more than "Granted" or "Denied." In a recent habeas claim by an inmate, the Kansas Court of Appeals got a motion from the inmate - shortly before the posted docket date at which his case would be decided without argument-seeking to represent himself. That was a strange request since it came well after briefing had been completed; if he had been dissatisfied with the briefs, he could have tried to do something much sooner.

A look at the case file showed that he had previously contacted the court clerk's office asking that when the decision came out a copy be sent to him directly (rather than relying on his attorney to send him one). Our clerk had apparently denied that request, perhaps because its computer system wasn't designed to send pleadings directly to represented parties. With that knowledge, though, his request to represent himself probably was just a second attempt to get the court to mail a copy of its decision directly to him. Whether that was the case or not, he needed more than the one-word response of "Granted" or "Denied." And hopefully his satisfaction with the legal system will be higher because he got one.

\section{B. Rules}

Today's court rules have largely been drafted by lawyers and are intended to be used by lawyers. Many things about court procedure are technical and complicated; no one expects first-year law students to take 
on an appeal as one of their early assignments.

But having an appellate-procedure system designed for lawyers is a mismatch for self-represented parties. And more and more often, parties on appeal are self-represented. In Colorado, for example, an author who looked into the hurdles self-represented litigants faced found that selfrepresented parties were present in about a third of appeals in the Colorado Court of Appeals and in the United States Court of Appeals for the Tenth Circuit. ${ }^{90}$

The courts are of course a branch of the people's government. So we should make sure that the people can access the courts.

Sometimes a relaxed standard is applied to self-represented parties. Federal courts generally give some leeway to self-represented parties based on the United States Supreme Court's statement in 1972 in Haines v. Kerner" ${ }^{91}$ that it would "hold [the complaint of a self-represented party] to less stringent standards than formal pleadings drafted by lawyers." ${ }^{92}$ In many state courts, that's not the case - state courts often say that the selfrepresented are held to the same standards as attorneys. ${ }^{93}$ But whether a self-represented party gets any leeway or not, it's easy to see how selfrepresented parties would be confused by many rules of appellate procedure.

As I thought about what a self-represented party might face, I thought back in my mind to the appeals I had handled as an attorney. I filed one petition for certiorari in the United States Supreme Court. That would have been daunting had there not been a former Supreme Court clerk who was then a fellow associate at my law firm. But a self-represented person would face many hurdles - even in pursuing a state-court appeal. The Missouri appellate courts have a rule, Supreme Court Rule 84.04(d), that prescribes a certain way a party must state the "points relied on" for the appeal. $^{94}$ It's the equivalent to Rule 28(a)(5) of the Federal Rules of Appellate Procedure, which tells you how to set out the issues on appeal

90. Marcy G. Glenn, Pro Se Civil Appeals: The Problem and Special Standards and Rules, 45 Colo. LAW. 63, 63 (2016). She found that $35 \%$ of non-criminal appeals in the state intermediate appellate court had at least one self-represented party in 2014, and $29 \%$ of non-criminal cases in the Tenth Circuit had at least one self-represented party in the cases pending as of December 2015. Id.

91. 404 U.S. 519 (1972).

92. Id. at 520 .

93. See, e.g., Rizzo v. State Farm Ins. Co., 305 P.3d 519, 529 (Idaho 2013) (stating that "[p]ro se litigants are held to the same standards and rules as litigants represented by an attorney"); Zavodnik v. Harper, 17 N.E.3d 259, 266 (Ind. 2014) (stating that "a pro se litigant is held to the same standards as a trained attorney"); Estate of Turcic, 164 A.3d 134, 135 (Me. 2017) (stating that "we hold pro se litigants to the same standards as represented litigants"); In re Estate of Tuckness, 403 S.W.3d 597, 598 (Mo. Ct. App. 2011) (stating that "[s]elf-represented litigants are held to the same standards as attorneys").

94. Mo. Sup. CT. R. 84.04(d). 
in a federal case. ${ }^{95}$ But Rule $84.04(\mathrm{~d})$ is much more idiosyncratic, detailed, and picky.

The Missouri Supreme Court did simplify the rule somewhat in a 1999 amendment. Before that amendment, commentators noted that "compliance was frequently troublesome" and "numerous appeals were dismissed." 96 The amended rule now includes a suggested format for points relied on. For review of a trial court decision, the suggested format now gives everyone at least a general idea of what's needed:

The point shall be in substantially the following form: "The trial court erred in [identify the challenged ruling or action], because [state the legal reasons for the claim of reversible error], in that [explain why the legal reasons, in the context of the case, support the claim of reversible error]."

That's helpful, especially for attorneys, but still pretty confusing for the self-represented. Or so it seems. Even under the amended rule, one of the three Missouri intermediate appellate courts, the Missouri Court of Appeals for the Western District, dismissed 13 appeals filed by selfrepresented parties for failure to comply with Rule 84.04(d) between January 2017 and August 2020. ${ }^{98}$ The confused litigants in those cases are unlikely to feel that their cases were handled fairly.

As the number of self-represented parties on appeal continues to rise, courts should consider whether changes in the rules could be made to make an appeal easier to navigate. Rules are usually drafted by committees made up of lawyers. Courts should have lay members on drafting

\footnotetext{
95. FED. R. APP. P. 28(a)(5).

96. Daniel P. Card II, Alan E. Freed \& James R. Layton, 24 Mo. PRAC., Appellate Practice § 7.8 (2d ed.), Westlaw (database updated Oct. 2020).

97. Mo. Sup. CT. R. 84.04(d)(1).

98. See Rauch v. Corizon Med., No. WD 83550, 2020 WL 4941765, at*3 (Mo. Ct. App. Aug. 25, 2020); Guglielmino v. Jackson Cnty., No. WD 82855, 2020 WL 4290055, at *2-3 (Mo. Ct. App. July 28, 2020); Equity Tr. Co. v. Givhan, 604 S.W.3d 921, 923 (Mo. Ct. App. 2020); Walker v. Div. of Emp't Sec., 592 S.W.3d 384, 388-89 (Mo. Ct. App. 2020); Holding v. Kan. City Area Transp. Auth., 584 S.W.3d 358, 361 (Mo. Ct. App. 2019); Callahan v. Precythe, 577 S.W.3d 159, 162 (Mo. Ct. App. 2019); Hoover v. Hoover, 581 S.W.3d 638, 640 (Mo. Ct. App. 2019); Hiner v. Hiner, 573 S.W.3d 732, 735-36 (Mo. Ct. App. 2019); Wallace v. Frazier, 546 S.W.3d 624, 627-28 (Mo. Ct. App. 2018); MoBay Props., LLC v. White, 540 S.W.3d 876, 879 (Mo. Ct. App. 2018); Dubroc v. Dubroc, 537 S.W.3d 369, 371-72 (Mo. Ct. App. 2017); Johnson v. Mo. Dep't of Corr., 534 S.W.3d 869, 872 73 (Mo. Ct. App. 2017); Mo. Dep’t of Soc. Servs., Fam. Support Div. v. Shipley, 517 S.W.3d 37, 3839 (Mo. Ct. App. 2017). Lest the reader think the Western District has a unique view of Rule 84.04(d), it does not. Similar dismissal orders against self-represented parties can be found in the Southern District, see, e.g., Steiner v. Rolfes, 602 S.W.3d 313, 315 (Mo. Ct. App. 2020); Scarlett Invs., LLC v. First Home Sav. Bank, 534 S.W.3d 291, 295 (Mo. Ct. App. 2017); Kyle Estate v. 21st Mortg. Corp., 515 S.W.3d 248, 252-53 (Mo. Ct. App. 2017); and the Eastern District, see, e.g., A.C.C. v. S.B., 568 S.W.3d 895, 897 (Mo. Ct. App. 2019); Unifund CCR Partners v. Myers, 563 S.W.3d 740, 742 (Mo. Ct. App. 2018).
} 
committees so that the public's voice can be heard on the rules that affect the public's right of access to the courts. Attorneys might well find simplified rules helpful too.

\section{Oral Argument}

The way a judge acts during oral argument leaves an impression about whether the judge genuinely seems to want to hear the litigant's position, acts in a respectful manner to the parties and their attorneys, and seems sincerely interested in a fair resolution. Judges can certainly argue about whether those are the primary purposes of oral argument. But if the public is viewing the judge's work through a procedural-justice lens, then a failure by appellate judges to consider this perspective when conducting oral argument risks alienating the public.

Consider the views of one litigant who attended an argument in the United States Supreme Court. Senator John McCain attended oral argument in Citizens United v. Federal Election Commission. ${ }^{99}$ After the decision came out, McCain said that he wasn't surprised by it: "I went over to observe the oral arguments .... It was clear that Justice[s] Roberts, Alito and Scalia, by their very skeptical and even sarcastic comments, were very much opposed to it." 100 McCain was left with the impression that these Justices, who McCain noted had no experience in the political arena, weren't really interested in understanding the perspective of others, including that of the majority of both houses of Congress. ${ }^{101}$ Leaving impressions like that is not healthy for the court system.

Now, one may say that this was an unusual case because most of the time, few, if any, members of the public come to watch appellate arguments. But public access to appellate courtrooms is changing. Most state supreme courts now offer streaming audio or video coverage, ${ }^{102}$ and a simple Google search for a judge's name can lead to a blog or other nontraditional account of someone's experience in that judge's court.

For those who do attend an oral argument in person, judges generally don't know who the people in the gallery are. Was the crime victim present when a judge made a cavalier comment? Did the judge seem to

\footnotetext{
99. 558 U.S. 310 (2010).

100. Michelle Levi, McCain: Campaign Finance Reform is Dead, CBS News: FaCE THE NATION (Jan. 24, 2010, 11:27 AM), https://www.cbsnews.com/news/mccain-campaign-financereform-is-dead/ [https://perma.cc/CL34-BT77].

101. See id.

102. As of 2017, Erwin Chemerinsky and Eric Segall reported that "[t]hirty-five state courts of last resort regularly live stream or televise their arguments." Erwin Chemerinsky \& Eric J. Segall, Cameras Belong in the Supreme Court, 101 JUdiCATURE 14, 14 (2017).
} 
care about the case as much as how much time was left for oral argument? Did the judge seem to pay attention at all? It's easy to think of many situations in which judges might give attendees a bad impression of the court system —one that could stick with them for a very long time.

\section{Opinions}

Appellate courts announce their decisions in written opinions. Those opinions can say a lot from a procedural-justice vantage point.

Opinions that skip over any recognition of the concerns of the parties may leave the impression that the court didn't care about them, especially if the case ended up being decided on something that seems like a legal technicality, such as the statute of limitations. Opinions written in something other than plain terms understood by a lay reader say that the court's intended audience is lawyers, not litigants or members of the public.

1. Writing for the Lay Audience

Judges have certainly differed over whether opinions should be written for a lay audience or for lawyers. But if we think about it from a procedural-justice viewpoint, only opinions written for a lay audience can gain acceptance from someone who values procedural justice. Can a litigant who finds that she can't understand portions of the opinion really feel that the judge cares about her? Will a litigant who doesn't understand the explanation of the legal principles involved feel that his case has been decided on neutral principles rather than judicial bias disguised in gobbledygook?

In most cases, the parties to the case are not lawyers. Even when we look at the broader audience for judicial opinions, web access has changed that audience. As an example, consider the number of people who went to look at Minnesota state appellate opinions during the first ten months of 2019. There are separate entry points for decisions of the Minnesota Supreme Court and the Minnesota Court of Appeals. Each entry point had about 150,000 different visitors during that time. ${ }^{103}$ Those numbers could not have been generated just by Minnesota lawyers.

When most of today's appellate judges went to law school, appellate opinions were mostly read by lawyers. So it was only natural that the

103. Email from Alyssa Siems Roberson, Dir. of Pub. Affairs, Minn. Jud. Branch to Steve Leben \& Kevin Burke (Oct. 29, 2019, 5:55 p.m.) (on file with author). Roberson said that there had been 154,310 visits to the Minnesota Supreme Court's opinion page and 147,400 visits to the Minnesota Court of Appeals opinion page during that time frame. 
opinions were written for lawyers. But that's not the state of things today. With ease of access, litigants and the public are reading appellate opinions. Their sense of procedural justice is enhanced if they understand the explanation for the decision and feel that the court listened to both sides. That sense will be diminished if they can't understand the decision or conclude that the court didn't take both sides seriously.

Writing for the lay audience adds another value too. Using language a lay person can understand will often expose flaws in legal reasoning that were hidden when the underlying concepts weren't explained. Sometimes a judge will find that the result that at first seemed appropriate really makes little sense. It's a rare case - if one exists - that a judge would not be able to explain to a high-school student, a family member, or any other nonlawyer if the judge really made that a goal for every opinion.

\section{The Opinion as a Letter to the Loser}

Writers from the field of therapeutic jurisprudence have suggested that courts make at least part of the opinion speak directly to the losing party. Nathalie Des Rosiers first made this suggestion in an article she wrote about a decision of the Supreme Court of Canada on a very divisive issue, Quebec secession. ${ }^{104}$ To show respect, Des Rosiers suggested that part of the court's opinion should essentially be a "letter to the loser." 105

Despite the contentious nature of Quebec secession, the court's decision was well received. ${ }^{106}$ Des Rosiers attributed that in part to how the court addressed in a respectful manner the issues raised by the losing party. ${ }^{107}$

The court acknowledged the complexity of the problem and the reasons each side offered so that "democracy [was] enhanced by the confrontation of reasons why one group should prevail over another." 108 Many United States judges could benefit from her advice to avoid demeaning the losing party: "A language that destroys one participant serves to exacerbate his or her sense of having been exploited, of being misunderstood, and of having no hope of being respected."109

Making sure that the losing party feels respected was the focus for Amy Ronner, a law professor who has run a clinic in which law students

104. Des Rosiers, supra note 87 , at 54,56 .

105. Id. at 56 .

106. Id. at 61 .

107. Id. at $61-62$.

108. Id. at 57 .

109. Id. 
represented indigent parties on criminal appeals, and Bruce Winick. ${ }^{110}$ They have contrasted two ways appellate courts handle these cases. ${ }^{111}$ In some, the court enters a short per curiam affirmance. ${ }^{12}$ In those cases, the court provides no discussion of the facts, no disclosure of the court's reasoning, and, in Ronner and Winick's view, "no sense of validation" to the losing party that the losing party's claims were fairly heard. ${ }^{113}$

In other cases, the court issues at least a short opinion explaining its decision. As Ronner and Winick note, even when the court must give a party an adverse decision, it still can "let individuals know that their arguments have been fairly and fully considered." 114

An appellate court shows that it has listened by noting at least the party's main points somewhere in the court's opinion. ${ }^{115}$ Instead of the per curiam affirmance, Ronner and Winick recommend that the court issue a very short written opinion that still notes the key facts, mentions at least some of the arguments, and explains why precedent calls for the result reached by the court. ${ }^{116}$ From a procedural-justice perspective, that's a much better practice.

Wexler has endorsed the "letter to the loser" recommendation to make sure litigants feel that their voice has been heard. ${ }^{117}$ He chose one of my opinions as an example. ${ }^{118}$

My court had a case in which a man who now lives in Africa had filed a court case to set aside the adoption of his biological son. ${ }^{119}$ This was not his first visit to the Kansas court system, and his new claim was barred by res judicata. But the district court had already told him that before he appealed; in his appeal, he listed 21 reasons he said the district court had erred. ${ }^{120} \mathrm{He}$ filed a 45 -page initial brief and a 12-page reply brief. ${ }^{121}$

The Kansas Court of Appeals' majority opinion told him that he had "fail[ed] to present a single reason why the district court erred in denying his motion as res judicata," but it neither addressed his separate claims nor

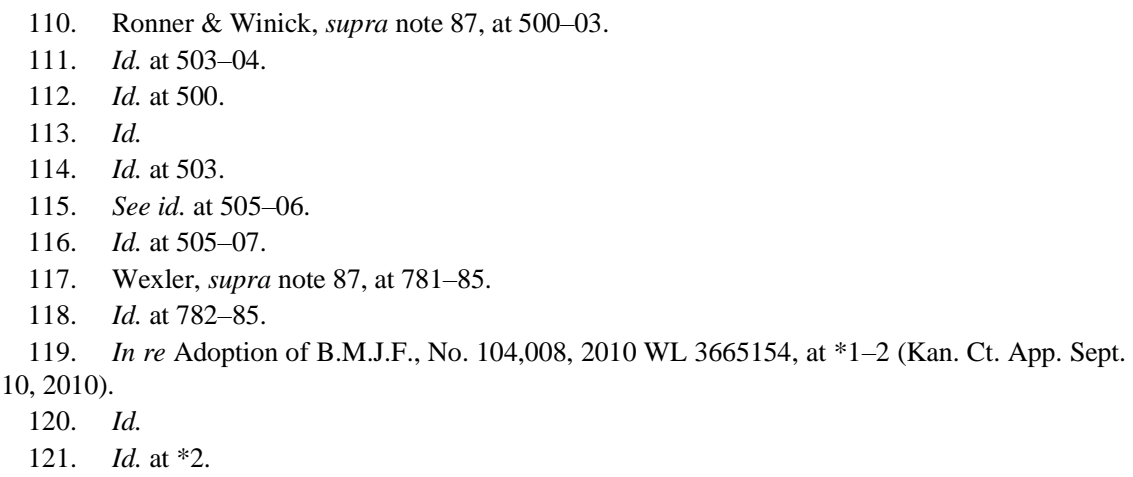


explained the concepts beyond res-judicata rules. ${ }^{122}$ The opinion was no doubt typical, though, of how most courts in the United States would resolve such a case: it provided the basic factual background, and it told the litigants that the father's attempt to reopen the adoption more than four years after it had been court-approved was too late and barred by the doctrine of res judicata. ${ }^{123}$

I was concerned, though, that he would have no idea what res judicata meant. So I wrote a six-paragraph concurring opinion (one that with minor revision could have served as the court's opinion). ${ }^{124}$ Wexler thought it provided an example of how appellate courts might tailor an opinion to focus on procedural-justice concepts through plain English and an explanation of the concepts at issue:

The history of N.M.'s sporadic appearances in the Kansas court system to reassert claims that he previously had abandoned suggests that he may not understand some of the overriding legal principles we must follow. I offer this concurring opinion in the hope that he may yet understand them. See Ronner, Therapeutic Jurisprudence on Appeal, 37 Ct. Rev. 64 (Spring 2000).

The American court system works hard to ensure that court proceedings involving children are resolved in as short a time frame as possible. We recognize that children deserve an answer to the most basic questions about their lives - like, who are my parents? Where will I live?-within a time frame that is reasonable as judged from a child's viewpoint.

The ultimate need for legal disputes to be resolved, so that people may get on with their lives and business affairs, is also the driving force behind the legal doctrine called res judicata. Under res judicata, when a dispute has been decided in a final court judgment, the same issues may not be relitigated in a later suit. That allows parties to go on about their business based on the court's final judgment without worrying that some later court action might yet revisit the same issues.

The court's opinion has correctly held that res judicata applies here. N.M.'s parental rights were terminated by the district court in its January 2003 ruling. N.M. appealed, but when he dismissed that appeal, the district court's ruling terminating his parental rights became a final judgment. And after that, the proposed adoptive parents proceeded with their adoption of B.M.J.F. based upon the final judgment, which terminated N.M.'s parental rights. So res judicata prevents further litigation over the matter.

Even if some exception to the res judicata rule were available — and I am

122. Id. at $* 2$.

123. Id. at $* 1-2$.

124. Id. at $* 2-3$ (Leben, J., concurring). 
not aware of one-this is exactly the sort of case in which we would be reluctant to apply it. This child has lived with the adoptive family from a few days after his birth in 2002 until now. From the time the adoption was finalized in October 2004 until N.M. filed pleadings in April 2009 seeking to reopen the case, the child's family knew that there was a final judgment terminating N.M.'s parental rights and an order of adoption in place. When we look at this situation from the standpoint of the child, he has had only one home and one family. He and his family have a right to rely upon the finality of the 2003 ruling terminating N.M.'s parental rights, a judgment that became final when N.M. voluntarily dismissed his appeal in 2004.

N.M.'s continued interest in his biological son is understandable, perhaps even laudable. But no matter its sincerity, it is no longer an interest that Kansas law can force this 8-year-old boy's adoptive parents to respond to. ${ }^{125}$

Obviously, I wasn't able to convince all the judges who served on appellate panels with me to apply procedural-justice principles in every case; after all, I wrote a concurrence, not the court's opinion. Truth be told, the difference here represents a real and reasonable point on which judges may disagree. An intermediate appellate court has a busy docket; its judges simply can't take the time to write every opinion as if it were the United States Supreme Court. Compromises often must be made between the dual goals of timeliness and thoroughness. But judges often could do more to make clear to losing litigants that, even though their key arguments had been heard, the court concluded that other considerations required a different result.

\section{Addressing the Bigger Picture}

Sometimes a court must not only address the losing party's arguments but must also place that argument into a larger context. The former chief judge of the Tenth Circuit, Deanell Tacha, argues that citizens lack a basic understanding of how our government works and urges that judges help solve this by becoming "painters of the "big picture." 126 While she primarily suggested speeches to civic clubs, presentations in schools, and other general education efforts, ${ }^{127}$ focusing on the big picture in opinions would also help in many cases from a procedural-justice perspective.

That's because we want parties and the public to understand the explanation a court's opinion provides about why the decision was made.

125. Id.

126. Deanell Reece Tacha, Renewing Our Civic Commitment: Lawyers and Judges as Painters of the "Big Picture", 41 U. KAN. L. REv. 481, 488 (1993).

127. Id. at $488-89$. 
Without that understanding, they can't assess the procedural fairness of the opinion. But without a grasp of the big picture - which they may well lack - they won't understand the true basis for the opinion.

A typical example would be a habeas corpus claim of ineffective assistance of counsel. The defendant is seeking to overturn a jury's verdict, and there are usually victims or family members of victims who will be upset if the guilty verdict is set aside. Sometimes, though, setting the guilty verdict aside is necessary: when a trial error leaves the appellate court in doubt that the verdict was fair, the court must set it aside and order a new trial. ${ }^{128}$ But if the court's opinion merely states the legal standards to be applied - without an explanation of why they're in place - the victims and the public may not understand why the decision was made.

There might be as many ways to address painting the big picture in such a case as there are judges, so my suggestions are just one option. In a dissent, I tried this first paragraph to put the case into context:

Our criminal-justice system uses the adversarial process to seek truth and provide fairness. On one side stands the government-with police officers and sheriff's deputies, crime labs, fingerprint and DNA databases, and prosecutors. On the other stands the defendant. This justice system works - providing a fair process to seek just results - only if the defendant has reasonably effective representation too. ${ }^{129}$

My hope was that such an introduction would set the stage for the reader to understand why, given the inadequacy of the representation provided, a new trial really was needed - even though the crime was especially cruel and gruesome.

Another simple big-picture item that often comes up in criminal appeals is the statement of the standard of review. Because the person has been convicted, either in a trial to a judge or a jury, the appellate court must look at the facts in the light most favorable to the government. ${ }^{130}$ After all, the fact-finder found in the government's favor.

But the way a court states that standard of review might make a lot of difference to the reader. For example, the Kansas Supreme Court frequently says that it "must determine whether, in a light most favorable to the prosecution, a rational fact-finder could have found [the defendant]

\footnotetext{
128. See, e.g., Wilson v. State, 340 P.3d 1213, 1230 (Kan. Ct. App. 2014).

129. Baker v. State, 457 P.3d 183, 196 (Kan. Ct. App. 2019) (Leben, J., dissenting).

130. See, e.g., State v. Toahty-Harvey, 298 P.3d 338, 341 (Kan. 2013) ("All of the evidence is reviewed, but not reweighed, to determine if there is sufficient support for the district court's factual findings."); Wilson, 340 P.3d at 1216-17.
} 
guilty beyond a reasonable doubt."131 Think about how a defendant and the defendant's family and supporters would feel when reading that the court has affirmed a guilty verdict and long sentence by taking all the facts in the light most favorable to the prosecution. Unless the court explains why it does so- that the facts were determined by the jury, for example, and the appellate court is not the finder of fact - the defendant may at least initially feel that the court was biased in favor of the prosecution. Explaining the big picture in a situation like this both helps educate everyone about how our system works and improves the understanding of the opinion necessary to a feeling of fair treatment.

\section{The SPecial CASE of THE United States SuPREME CourT}

Earlier in this Article, I reviewed the data on diminished perceptions of legitimacy and trust for the United States Supreme Court. ${ }^{132}$ This should matter to the Court; our judicial system as a whole needs its highest court to be well-respected. From a procedural-justice perspective, three focal points come into view: (1) opening the Court's oral arguments to television; (2) writing opinions that explain the big picture for the lay reader; and (3) providing a better explanation when the Court handles matters through what's commonly called its "shadow docket."

\section{A. Opening Oral Arguments to Television}

Most state supreme courts now routinely provide live-streams or broadcasts of their oral arguments; so do many federal courts of appeal. ${ }^{133}$ But the United States Supreme Court, the world's most powerful court, normally does not. ${ }^{134}$ From a procedural-justice vantage point, the Court is therefore not transparent to all but a sliver of the population, the people who are lucky enough to get a seat in the courtroom for an argument. The Court does release audio recordings and transcripts. ${ }^{135}$ But our modern society does not access information through same-day transcripts and

131. State v. Cottrell, 445 P.3d 1132, 1143 (Kan. 2019) (emphasis added) (citing State v. Raskie, 269 P.3d 1268, 1278 (Kan. 2012)).

132. See supra notes $14-44$ and accompanying text.

133. Chemerinsky \& Segall, supra note 102, at 14. See, e.g., Listen to Oral Arguments, U.S. CT. OF APPEALS FOR THE 4TH CIR., https://www.ca4.uscourts.gov/oral-argument/listen-to-oral-arguments [https://perma.cc/KJ7V-4FP6] (last visited Oct. 13, 2020); Archived Audio and Video, U.S. CTS. FOR THE 9TH CIR., https://www.ca9.uscourts.gov/media/ [https://perma.cc/D96W-4LK4 ] (last visited Oct. 13, 2020); Recent Oral Arguments, U.S. CT. OF APPEALS FOR THE 10TH CIR., https://www.ca10.uscourts.gov/oralargument/search/recent [https://perma.cc/PE6Q-6YG5] (last visited Oct. 13, 2020).

134. Chemerinsky \& Segall, supra note 102, at 14.

135. Id. at 15 . 
audio recordings released even later, as the Court's normal procedures provide. ${ }^{136}$

The Court did make a limited exception to its access rules during the Covid-19 pandemic. Since the Court wasn't able to convene in personeither with all the Justices together or with counsel - the Court had to turn to some form of electronic access to hold oral arguments at all. ${ }^{137}$ While most state supreme courts opted for a videoconferencing solution, such as Zoom, the United States Supreme Court used an audio conference call, and the Court made that audio stream accessible to the media and the public. ${ }^{138}$ "Millions of people listened," 139 and public-opinion surveys showed broad support for live access to the Court's proceedings. ${ }^{140}$

Procedural-justice research shows that procedural concerns are important in the evaluation of authorities and institutions. ${ }^{141}$ Tyler and another researcher found a connection in some 1987 survey data between the public's impression of the Court's procedural fairness and the public's view of the Court's legitimacy. ${ }^{142}$ So there's reason to believe that improving perceptions of fairness would lead to a better sense that the Court's authority is legitimate.

Opening oral arguments to public broadcast could help. The Court had a chance to show the public that its process was fair when it heard the first cases over the Affordable Care Act in 2012. ${ }^{143}$ The Court set aside three days for oral argument, and the nation's 24-hour news cycle focused

136. See id. The Court releases audio recordings at the end of the week.

137. See Erwin Chemerinsky, Chemerinsky: SCOTUS Should Embrace Technology Reforms Prompted by Pandemic, ABA J. (May 28, 2020, 9:07 AM), https://www.abajournal.com/news/article/chemerinsky-scotus-should-embrace-technology-reformsprompted-by-pandemic [https://perma.cc/6US2-WHHA].

138. Id.

139. Id. See also Kalvis Golde, Public Approves of Live Access to Supreme Court Arguments, Polls Show, SCOTUSBLOG (May 21, 2020, 3:20 PM), https://www.scotusblog.com/2020/05/publicapproves-of-live-access-to-supreme-court-arguments-polls-show/ [https://perma.cc/H4EX-NZWK].

140. Golde, supra note 139 ("83 percent of those polled agreed with the [Court's] decision to provide live audio during the pandemic, and 70 percent believed the $[\mathrm{C}$ ]ourt should continue with live audio once things return to normal.").

141. Tom R. Tyler \& Kenneth Rasinski, Procedural Justice, Institutional Legitimacy, and the Acceptance of Unpopular U.S. Supreme Court Decisions: A Reply to Gibson, 25 LAW \& SOC'Y REV. 621,628 (1991).

142. Id. at 624-28.

143. For a more comprehensive review of the Court's performance at these oral arguments, see Steve Leben \& Kevin Burke, Supreme Court Gets a Passing Grade on Procedural Fairness-So Far, PROCEDURAL FAIRNESS BLOG (April 3, 2012) [hereinafter Leben \& Burke, Supreme Court Gets a Passing Grade on Procedural Fairness], https://proceduralfairnessblog.org/2012/04/03/supreme-court-gets-a-passing-grade-onprocedural-fairness-so-far/ [https://perma.cc/JG7L-J5YG]. 
on the cases. ${ }^{144}$ When asked, members of the public overwhelmingly favored having those hearings televised. ${ }^{145}$ But the public had no ability to hear the arguments - or even excerpts of them during those news cycles. The public had no chance to see for itself whether the Court had provided fair hearings.

Had they been broadcast, I've argued that the public's perception of the hearings would have been positive. ${ }^{146}$ Minneapolis trial judge Kevin Burke and I looked at the justices' performance during those oral arguments. ${ }^{147}$ On the whole, we found that the justices acted evenhandedly and asked appropriate questions of both sides. ${ }^{148}$ That was especially true for the two most critical members of the Court, Chief Justice John G. Roberts, Jr., who presided, and Justice Anthony Kennedy, widely regarded then as the key swing vote for most cases on the Court. ${ }^{149}$

The Court has the ability at oral argument-if televised-to demonstrate to the public that it is sincerely interested in the parties' arguments and trying to decide the case based on neutral principles. ${ }^{150}$ If the performance of justices does not show that, justices would have a chance to learn that; commentators, both academic and otherwise, would no doubt provide feedback.

The main arguments made against broadcasting the arguments are that attorneys or justices might change their behavior and that the public might be misled as excerpts are broadcast. ${ }^{151}$ But state courts have not had a problem with grandstanding attorneys (or justices). ${ }^{152}$ And members of the public who wanted to watch the Court's hearings in full (and many no doubt would) could do so on CSPAN or on the web. That video clips may

144. See, e.g., Adam Liptak, In Health Care Case, Lawyers Train for 3-Day Marathon, N.Y. TIMES (Mar. 25, 2012), https://www.nytimes.com/2012/03/26/us/in-supreme-court-healthcare-case-training-for-a-legal-marathon.html [https://perma.cc/W9JC-FGTP]; Brian Stelter, CNN and Fox Trip Up in Rush to Get the News on the Air, N.Y. TIMES (June 28, 2012), https://www.nytimes.com/2012/06/29/us/cnn-and-foxs-supreme-court-mistake.html [https://perma.cc/98TL-MMZF].

145. Lydia Saad, Americans Favor Televising Supreme Court Healthcare Case, GalluP (Dec. 9, 2011), https://news.gallup.com/poll/151445/americans-favor-televising-supreme-court-healthcarecase.aspx [https://perma.cc/9CGE-GZHW] (stating that $72 \%$ of those polled were in favor).

146. Leben \& Burke, Supreme Court Gets a Passing Grade on Procedural Fairness, supra note 143.

147. Id.

148. Id.

149. Id.

150. See Steve Leben \& Kevin S. Burke, Opinion, Supreme Court Itself Will Be Tested as It Hears Health-Case Arguments, MinnPost (March 26, 2012), https://www.minnpost.com/community-voices/2012/03/supreme-court-itself-will-be-tested-it-hearshealth-case-arguments/ [https://perma.cc/R6JA-U7TC].

151. Chemerinsky \& Segall, supra note 102, at 15-16.

152. Id. 
be used - and might have snippets that put Justices in a bad light - is no different than having audio clips used now, albeit on a delayed basis, or having the media simply choose what is most important in the story, as they must do to report it.

\section{B. Writing Opinions That Better Explain the Big Picture}

The earlier discussion about explaining the big picture ${ }^{153}$ applies even more to the Supreme Court. And one of its well-publicized opinions, Kelo v. City of New London, ${ }^{154}$ is a good example.

Kelo, which upheld a city's use of its eminent-domain power, ${ }^{155}$ was one of the Court's most unpopular decisions in recent decades. One of the two times the Gallup Poll approval of the Court has dipped to $42 \%$ came in the immediate aftermath of the Kelo decision. ${ }^{156}$

When one looks at the Kelo opinion, it reads like a typical legal discussion of abstract concepts. Perhaps had it been written more for the lay reader - and emphasized the leeway that a court must give to elected officials - the negative public reaction might have been lessened. ${ }^{157}$ After all, the Court's decision simply left in place a decision that had been made by local elected officials. ${ }^{158}$

Although it came up in a trial court, I had a case that shows at least in part how this might be handled. The case involved the "appeal of a city's approval of a large auto mall in one of the Kansas-side suburbs of Kansas City. The appeal was filed by neighboring property owners and their homeowners association, each of [which] had opposed the rezoning before the city commission." ${ }^{159}$ In Kansas, reviews of a city commission decision like this came to the trial court.

In a 15-page written opinion, along with noting that I had reviewed the full 2,600-page administrative record, I devoted a full page of the opinion to a discussion of the role of a court in zoning matters. ${ }^{160} \mathrm{I}$ began by explaining that elected officials had made the decision:

We live in a democracy in which many of the important decisions to be made that affect our lives are rightly to be made by our elected officials.

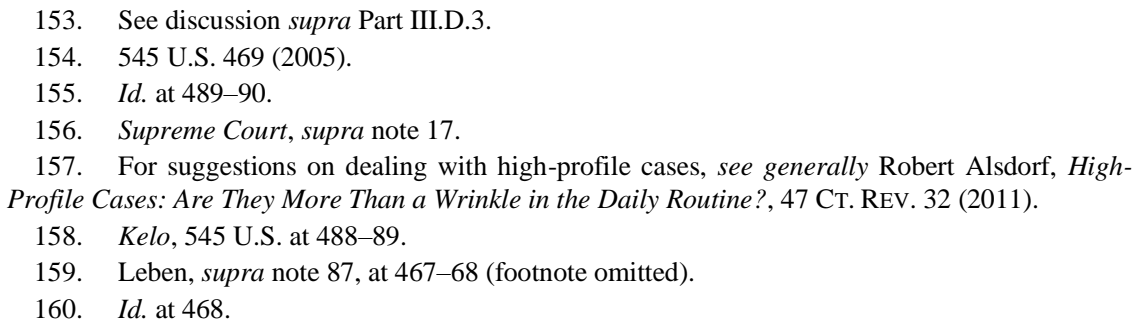


Although the consideration by a city council of a rezoning request is deemed a quasi-judicial proceeding, the initial decision is to be made by elected officials, not judges. It is in the making of that initial decision that a great deal of discretion exists. In a given case, it might well be a reasonable decision either to grant or to deny the requested rezoning, and the decision would depend upon the elected body's preferences for its city's development. ${ }^{161}$

That introduction set the stage for further discussion of the court's formal standard of review, under which the elected body makes a decision that must be upheld unless it is well beyond the range of potentially reasonable decisions. ${ }^{162}$

In Kelo, as in that case, a court was deferring to local elected officials-within legal limits. ${ }^{163}$ Many people who would be upset by eminent-domain powers or by an auto mall coming into their neighborhood might well agree that, on balance, they wouldn't want courts to interfere with the judgments of their elected officials unless truly necessary. In each case, part of the court's job should be explaining how our system works and where the court's role properly resides.

Painting that big picture lets the public put the court's decision in context. And without context, the decision is likely not going to be well understood. Procedural justice demands good explanations of decisions.

\section{Better Explanations on the "Shadow Docket"}

If good explanations are needed, that surely is the case on the Supreme Court's so-called shadow docket. The shadow docket is the Court's version of motion practice and summary decisions that don't get full briefing or oral argument. ${ }^{164}$ Good explanations are needed because the Court is making important decisions here.

Some of these decisions are literally life-and-death matters in death penalty cases. In one 2019 decision, the Court entered a five-to-four order lifting a stay of execution in a death-penalty case, Dunn v. Ray. ${ }^{165}$ Justice

\footnotetext{
161. Id.

162. Id. at 468-69.

163. Kelo, 545 U.S. at $488-90$.

164. Stephen I. Vladeck, The Solicitor General and the Shadow Docket, 133 HARV. L. REv. 123, 125 (2019). For a thorough review of the Court's shadow docket, see also William Baude, Forward: The Supreme Court's Shadow Docket, 9 N.Y.U. J.L. \& LIBERTY 1 (2015). Professor Vladeck provides an update on the Court's shadow docket in Steve Vladeck, The Supreme Court's Most Partisan Decisions Are Flying Under the Radar, SLATE (Aug. 11, 2020, 12:12 PM), https://slate.com/news-and-politics/2020/08/supremecourt-shadow-docket.html [https://perma.cc/P2UV-FJEA].
}

165. 139 S. Ct. 661, 661 (2019). 
Kagan, joined by three others, issued a strong dissent. ${ }^{166}$ But the majority's opinion-letting the execution proceed immediately-said only this:

The application to vacate the stay of execution of sentence of death entered by the United States Court of Appeals for the Eleventh Circuit on February 6, 2019, presented to Justice THOMAS and by him referred to the Court, is granted.

On November 6, 2018, the State scheduled Domineque Ray's execution date for February 7, 2019. Because Ray waited until January 28, 2019 to seek relief, we grant the State's application to vacate the stay entered by the United States Court of Appeals for the Eleventh Circuit. See Gomez v. United States Dist. Court for Northern Dist. of Cal., 503 U.S. 653, 654, 112 S.Ct. 1652, 118 L.Ed.2d 293 (1992) (per curiam) (“A court may consider the last-minute nature of an application to stay execution in deciding whether to grant equitable relief."). ${ }^{167}$

The same thing happened a few weeks later in Dunn v. Price. ${ }^{168}$ Justice Breyer, joined by three others, issued a dissent. ${ }^{169}$ But the majority's opinion allowing the execution to proceed said only this:

The application to vacate the stay of execution, presented to Justice THOMAS and by him referred to the Court, is granted, and the stays entered by the District Court for the Southern District of Alabama and the United States Court of Appeals for the Eleventh Circuit on April 11, 2019, are vacated. In June 2018, death-row inmates in Alabama whose convictions were final before June 1, 2018, had 30 days to elect to be executed via nitrogen hypoxia. Ala. Code $\S 15-18-82.1(b)(2)$. Price, whose conviction became final in 1999, did not do so, even though the record indicates that all death-row inmates were provided a written election form, and 48 other death-row inmates elected nitrogen hypoxia. He then waited until February 2019 to file this action and submitted additional evidence today, a few hours before his scheduled execution time. See Gomez v. United States Dist. Court for Northern Dist. of Cal., 503 U.S. 653, 654, 112 S.Ct. 1652, 118 L.Ed.2d 293 (1992) (per curiam) ("A court may consider the last-minute nature of an application to stay execution in deciding whether to grant equitable relief."). ${ }^{170}$

In matters of this importance, it's hard for the public to see procedural fairness in this kind of a proceeding.

A few days before Price, in another five-to-four death-penalty case,

166. Id. at 661-62 (Kagan, J., dissenting).

167. Id. at 661 (majority opinion).

168. 139 S. Ct. 1312, 1312 (2019).

169. Id. at 1312-15 (Breyer, J., dissenting).

170. Id. at 1312 (majority opinion). 
members of the Court expanded on the reasons for these types of rulings. ${ }^{171}$ But that would be of no use, obviously, to the men already executed. And it would not erase the public perception that came from the largely unexplained exercise of great discretion.

In an article coauthored by former Texas Supreme Court Chief Justice Wallace B. Jefferson, former California state court administrator William C. Vickrey, and California state judiciary analyst Douglas D. Denton, those authors outline the role a state high court has in explaining its decisions. ${ }^{172}$ Recognizing that opinions of the state court system will be affected by public impressions about its opinions, they urge writing key portions of the opinion (including the opening) in plain language; including a summary in any long opinion; and having good communications with the media to help in publicizing opinions. ${ }^{173}$ The summary opinions quoted above from the Supreme Court in these deathpenalty cases are far from the best practices Jefferson, Vickrey, and Denton have recommended for state high courts. The Supreme Court should consider the procedural-justice perceptions its handling of the shadow docket creates.

\section{CONCLUSION}

Given the relatively low level of public trust in institutions and the courts today, courts should consider taking steps likely to improve the public sense of the courts' legitimacy. At least at the trial level and on an overall basis, adherence to procedural-justice principles is shown to improve trust in courts and judges. While we do not have studies focused on groups of litigants in specific appellate courts, it's reasonable to think that adherence to procedural-justice principles would work similarly for appellate courts. The suggestions made in this Article would be sensible ones for courts to consider.

Of course, procedural-justice concepts aren't by themselves an adequate checklist of what judges or a justice system must do. In addition to procedural aspects, courts and judges still need to get the outcome right. And they must process cases expeditiously, which is not an explicit procedural-justice construct. But if we want the public to perceive courts as legitimate, getting it right isn't enough.

171. See Bucklew v. Precythe, 139 S. Ct. 1112, 1133-34 (2019).

172. Vickrey et al., supra note 1.

173. Id. at 79-81. 